\title{
ALTERNATIF AMPAS TAHU YANG DIFERMENTASI DENGAN PROBIOTIK SEBAGAI PAKAN TAMBAHAN TERHADAP PERTUMBUHAN NILA (Oreochromis niloticus)
}

\author{
Endah Sih Prihatini* \\ *Fakultas Perikanan Universitas Islam Lamongan \\ Jl. Veteran no. 53A Lamongan Phone/Fax.0322_324706
}

\begin{abstract}
ABSTRAK
Usaha budidaya ikan sangat dipengaruhi oleh ketersediaan pakan yang cukup dalam jumlah dan kualitasnya akan mempercepat kelangsungan dan pertumbuhan. Ampas tahu merupakan salah satu alternatif pengganti pakan buatan yang cukup murah dan mudah didapat. Tujuan penelitian ini adalah untuk mengetahui pengaruh ampas tahu yang difermentasi dengan probiotik sebagai pakan tambahan terhadap pertumbuhan ikan nila . Metode penelitian yang digunakan adalah eksperimen dengan rancangan acak lengkap. Media yang digunakan adalah bak dengan volume air 50 liter dengan kepadatan benih nila 50 ekor dengan panjang $1-2 \mathrm{~cm}$ dan berat 1-2 gr. Pertumbuhan diukur pada awal pemeliharaan, setiap minggu sekali selama satu bulan. Perlakuan yang digunakan adalah A (Perlakuan tanpa ampas tahu), B(Perlakuan ampas tahu 25\% yang difermentasi dengan probiotik), C(Perlakuan ampas tahu 50\% yang difermentasi dengan probiotik), D (Perlakuan ampas tahu $75 \%$ yang difermentasi dengan probiotik).diulang lima kali. Hasil penelitian didapatkan perlakuan $\mathrm{C}$ yang terbaik diikuti perlakuan B, A dan D. Penelitian ini disimpulkan bahwa pemberian ampas tahu yang difermentasi dengan probiotik berpengaruh nyata pada pertumbuhan.ikan nila dan disarankan penelitian pada skala yang lebih besar misal pada tambak atau sawah tambak.
\end{abstract}

Kata Kunci : Ampas Tahu, Pertumbuhan, Ikan Nila

\section{PENDAHULUAN}

Ikan nila (Oreochromis niloticus) merupakan ikan yang mempunyai keunggulan antara lain laju pertumbuhan cepat, tahan terhadap penyakit, toleransi yang tinggi, nilai ekonomis yang tinggi (Charraborty Banerjee, 2009).

Usaha budidaya ikan sangat dipengaruhi oleh ketersediaan pakan yang cukup dalam jumlah dan kualitasnya akan mempercepat kelangsungan dan pertumbuhan. Faktor pakan menentukan biaya produksi mencapai 60-70\%. Peningkatan produksi yang tinggi sangat tergantung pada pemilihan bahan pakan ikan. Bahan pakan yang mempunyai nilai ekonomis yang tinggi, mudah diperoleh harganya murah didapatkan pada ampas tahu (Wibowo, 2014).

Penerapan probiotik dalam usaha budidaya terbukti dapat meningkatkan resistensi biota yang dibudidayakan (udang/ ikan) terhadap infeksi, karena penggunaan probiotik merupakan salah satu cara preventif yang dapat mengatasi penyakit. Probiotik (bakteri pengurai) adalah mikroorganisme hidup yang sengaja dimasukkan ke dalam tambak untuk memberi efek menguntungkan 
bagi kesehatan udang/ikan (Mulyadi, dkk, 2002).

Tujuan probiotik, memperbaiki dan mempertahankan lingkungan, menekan bakteri merugikan, menghasilkan enzim yang dapat membantu sistem pencernaan, menghasilkan nutrisi yang bermanfaat serta meningkatkan kekebalan udang/ ikan (Irianto, 2003).

Kandungan gizi ampas tahu protein 26,6 gr, kalori 414 kilo kalori, karbohidrat 41,3 gr, lemak, 18,39 gr, ca $19 \mathrm{mg}, \mathrm{F} 29 \mathrm{mg}$, Fe $4 \mathrm{mg}$, Vit A $0,14 \mu \mathrm{Vit} \mathrm{B}_{1} 0,2 \mathrm{mg}$, dari $100 \mathrm{gr}$ ampas tahu Kementrian Kesehatan RI dalam Wibowo (2004). Alternatif fermentasi pakan tahu dengan probiotik sebagai pakan tambahan diharapkan bisa meningkatkan pertumbuhan yang tinggi dikarenakan ampas tahu adalah limbah harganya murah, mudah diolah, fermentasi dengan probiotik akan dapat membantu daya cerna ikan (Handajani, 2006).

Kemampuan daya cerna ikan terhadap pakan dilakukan dengan penambahan probiotik yang mempunyai pengaruh menguntungkan yaitu mendegradasi bahan yang tidak tercerna dan memecah komponen yang tidak tercerna dalam pakan dengan enzim yang mampu melakukan lisis terhadap amylase dan protease (Irianto dan Austin, 2002).

Selain itu sisa ampas tahu yang ada di perairan akan terurai menjadi zat yang sederhana menjadi pakan plankton di perairan sehingga mengurangi pakan komersial, mengingat nila adalah bersifat filter feelder (penyaring plankton) (Gustiano dan Arifin, 2010).

Oleh karena itu perlu dilakukan kegiatan penelitian tentang penggunaan ampas tahu yang difermentasi dengan probiotik sebagai bahan tambahan terhadap pertumbuhan nila (Oreochromis niloticus)

\section{METODE PENELITIAN}

Tempat dan Waktu

Penelitian ini dilaksanakan pada tanggal 15 Mei s/d 14 Juni 2017 di Kelurahan Sidokumpul Lamongan.

Metode penelitian yang digunakan eksperimen yaitu penelitian dengan melakukan percobaan, melihat pengaruh perlakuan terhadap hasil. Hasil yang akan didapat menegaskan bagaimana hubungan sebab antara variabel yang diteliti dan seberapa besar hubungan sebab akibat dengan cara memberikan perlakuan tertentu pada beberapa kelompok eksperimen dan menyediakan kontrol untuk perbandingan (Hanafiah, 2014). Variabel penelitian terdiri dari variabel bebas yaitu ampas tahu yang difermentasikan dengan probiotik (x) dan variabel terikat ialah pertumbuhan panjang dan berat ikan nila (y). Lay out penelitian (gambar 1) bisa dilihat di bawah ini

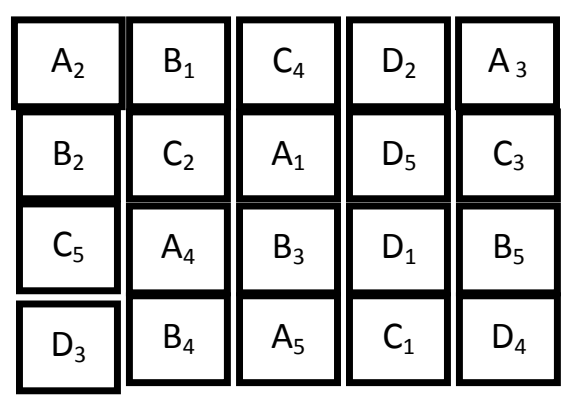

Gambar 1.Lay out penelitian

Keterangan :

A: Perlakuan tanpa ampas tahu

B : Perlakuan ampas tahu 25\% yang difermentasi dengan probiotik

$\mathrm{C}$ :Perlakuan ampas tahu 50\% yang difermentasi dengan probiotik

D :Perlakuan ampas tahu $75 \%$ yang difermentasi dengan probiotik

1, 2, 3, 4 dan 5 ulangan.

Persiapan Penelitian

Ampas tahu dengan berat satu kilogram (kg) sebelum digunakan perlakuan 
difermentasi dengan probiotik $1 \mathrm{ml}$ ditambah $10 \mathrm{ml}$ air. Setelah itu ditimbang sesuai dengan pemberian prosentase ampas tahu.

\section{A. Pelaksanaan Penelitian}

Bak diisi air dengan volume 50 liter dengan kepadatan 50 ekor berjumlah 20 buah diatur sesuai dengan lay out penelitian, diberi aerator yang berfungsi untuk menambah oksigen. Ikan nila yang digunakan berukuran 1-2 cm dengan berat 1-2 gr. Selama pemeliharaan ikan nila diberikan pakan pellet dengan pemberian 3\% dari berat tubuh dan frekuensi $2 \mathrm{x}$ sehari, pagi dan sore. Setiap minggu sekali dilakukan penimbangan untuk mengetahui laju pertumbuhan dan pemberian pakan yang diberikan. Pengukuran kualitas air antara lain suhu, oksigen terlarut, $\mathrm{NH}_{3}, \mathrm{pH}$ Sebagai Data penunjang.

Pengumpulan Data

Laju pertumbuhan ikan nila dilakukan dengan pengukuran berat ikan nila pada awal dan akhir percobaan. Dan dihitung dengan rumus (Zooneveld dan Boon: 1991)

Pertumbuhan mutlak $\rightarrow$

$$
\begin{aligned}
& \mathrm{W}=\mathrm{W}_{1}-\mathrm{W}_{0} \\
& \mathrm{~W}=\text { Pertumbuhan berat mutlak } \\
& \mathrm{W}_{0}=\text { Berat nila awal } \\
& \mathrm{W}_{1}=\text { Berat nila akhir. } \\
& \text { Pertumbuhan panjang } \\
& \mathrm{P}=\mathrm{P}_{1}-\mathrm{P}_{0} \\
& \mathrm{P}=\text { Pertumbuh panjang mutlak } \\
& \quad(\mathrm{cm}) \\
& \mathrm{P}_{0}=\text { Panjang rata-rata awal } \\
& \mathrm{P}_{1}=\text { Panjang nila akhir. }
\end{aligned}
$$

\section{HASIL PENELITIAN}

\begin{tabular}{|c|c|c|c|c|c|c|c|}
\hline \multirow{2}{*}{ Perlakuan } & \multicolumn{5}{|c|}{ Berat Tubuh Ikan (gr) } & \multirow{2}{*}{ Total } & \multirow{2}{*}{$\begin{array}{c}\text { Rata- } \\
\text { rata }\end{array}$} \\
\hline & 1 & 2 & 3 & 4 & 5 & & \\
\hline A & 2,5 & 3,5 & 3,5 & 3 & 2,5 & 15,0 & 3 \\
\hline B & 5 & 3,8 & 4 & 5 & 3,7 & 21,5 & 4,3 \\
\hline $\mathrm{C}$ & 7 & 6 & 5,1 & 4,8 & 3,75 & 26,65 & 5,33 \\
\hline $\mathrm{D}$ & 3,2 & 2 & 2,3 & 2,5 & 2 & 12,0 & 2,4 \\
\hline \multicolumn{6}{|c|}{ TOTAL } & 75,15 & 15,03 \\
\hline
\end{tabular}

Hasil anova (analisa varian) penelitian pemberian ampas tahu yang difermentasi

\begin{tabular}{|c|c|c|c|c|c|c|c|}
\hline \multirow{2}{*}{ Perlakuan } & \multicolumn{5}{|c|}{ Panjang Ikan (cm) } & \multirow{2}{*}{ Total } & \multirow{2}{*}{$\begin{array}{c}\text { Rata- } \\
\text { rata }\end{array}$} \\
\hline & 1 & 2 & 3 & 4 & 5 & & \\
\hline A & 2,5 & 3 & 3 & 3,8 & 4,1 & 16,4 & 3,28 \\
\hline $\mathrm{B}$ & 3,5 & 5,2 & 5,5 & 4,7 & 3,9 & 22,8 & 4,56 \\
\hline $\mathrm{C}$ & 4,5 & 5,9 & 4,8 & 5 & 7 & 27,2 & 5,44 \\
\hline $\mathrm{D}$ & 2,6 & 2,7 & 3,7 & 2,4 & 3 & 14,4 & 2,88 \\
\hline \multicolumn{6}{|c|}{ TOTAL } & 80,8 & 16,16 \\
\hline
\end{tabular}
dengan probiotik berpengaruh pada pertumbuhan panjang tubuh maupun berat tubuh Ikan Nila $(\mathrm{P}<0,5)$. Hasil penelitian pengaruh ampas tahu yang difermentasi dengan probiotik bisa dilihat pada tabel 1 dan tabel 2 di bawah ini:

Tabel 1. Hubungan pemberian probiotik pada ampas tahu dengan berat tubuih ikan

Tabel 2. Pengaruh pemberian probiotik pada ampas tahu dengan pertumbuhan panjang ikan

Grafik diagram batang ampas tahu yang difermentasi probiotik dengan pertumbuhan bisa dilihat pada gambar 2 dan gambar 3 dibawah ini 


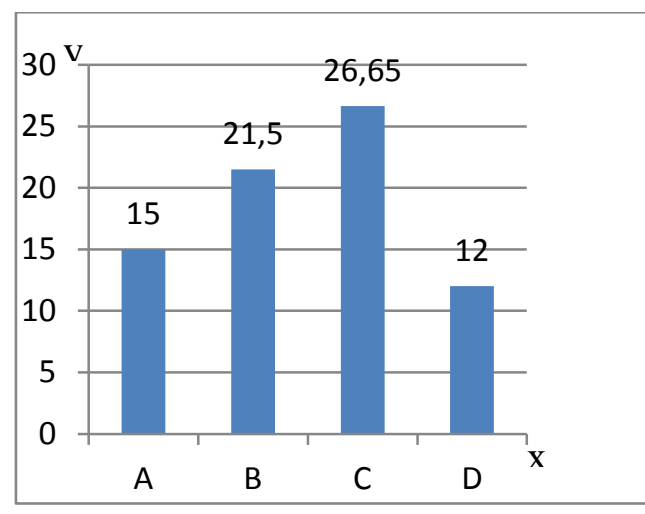

Gambar 2 Grafik diagram batang pemberian ampas tahu yang difermentasi dengan Probiotik terhadap pertumbuhan berat tubuh Ikan Nila

Keterangan :

A : Tanpa ampas tahu

B : Ampas tahu 25\% yang difermentasi dengan probiotik

C : Ampas tahu 50\% yang difermentasi dengan probiotik

D : Ampas tahu 75\% yang difermentasi dengan probiotik

$\mathrm{x}$ : Ampas tahu yang difermentasi dengan probiotik

y : Berat tubuh ikan nila

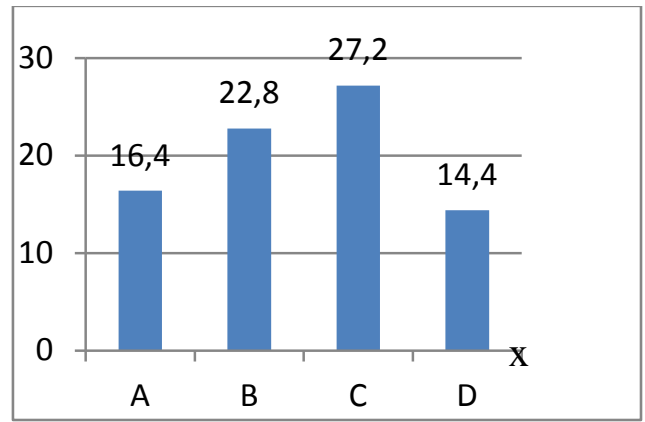

Gambar 3 Grafik diagram batang pemberian ampas tahu yang difermentasi dengan Probiotik terhadap Pertumbuhan panjang tubuh Ikan Nila

Keterangan :

A : Tanpa ampas tahu

B : Ampas tahu 25\% yang difermentasi dengan probiotik

C : Ampas tahu 50\% yang difermentasi dengan probiotik

D : Ampas tahu 75\% yang difermentasi dengan probiotik $\mathrm{x}$ : Ampas tahu yang difermentasi dengan probiotik

y : Panjang tubuh ikan nila

\section{PEMBAHASAN}

Pada perlakuan C (perlakuan 50\% ampas tahu dan $50 \%$ pellet) memberikan pertumbuhan yang tinggi disebabkan ampas tahu mengandung protein yang baik untuk pertumbuhan ikan nila, Selain itu sisa ampas tahu ramah lingkungan dan bisa menjadi media tumbuhnya plankton yang menjadi pakan tambahan ikan nila (Wibowo: 2014). Gustiano dan Arifin (2010) ikan nila bersifat filter feeder artinya memakan makanan dan menyaring lewat insangnya dalam hal ini plankton yang ada pada perairan menjadi pakan tambahan ikan sehingga pemberian pakan pellet bisa efiisien. Perlakuan A memberikan pertumbuhan yang lebih tinggi dari perlakuan D disebabkan pakan pellet mengandung protein yang tinggi untuk pertumbuhan ikan nila. Perlakuan D menghasilkan pertumbuhan terendah disebabkan pemberian ampas tahu saja tidak cukup memberikan hasil pertumbuhan yang tinggi karena kandungan proteinnya lebih rendah daripada protein pellet. Fermentasi pada ampas tahu memberikan dampak positif pada perairan karena dapat membantu penguraian senyawa komplek menjadi sederhana.

Penelitian tentang pengaruh pemberian ampas tahu terhadap pertumbuhan ikan nila memberikan hasil yang terendah sampai dengan yang tertinggi sebagai berikut : Perlakuan D, A, B, C

Pellet mengandung berbagai zat antara lain : protein ikan, lemak, vitamin, mineral yang lebih lengkap sehingga bisa memberikan pertumbuhan yang lebih tinggi. (Wibowo, 2014).

Kualitas air pada penelitian ini antara lain adalah suhu $28-30{ }^{\circ} \mathrm{C}, \mathrm{pH} 7,8-8,2$, 
oksigen terlarut $5-6 \mathrm{ppm}, \mathrm{NH}_{3} 0,01-0,02$ ppm, hal ini adalah layak menurut Kordi dan Tancung (2007) bahwa suhu antara $28-37$ ${ }^{\circ} \mathrm{C}$, pH 6,5-9, oksigen terlarut $5-7 \mathrm{ppm}$, $\mathrm{NH}_{3} 0,01-0,05 \mathrm{ppm}$.

\section{KESIMPULAN}

Pemberian Ampas Tahu yang difermentasi dengan probiotik berpengaruh nyata pada pertumbuhan berat tubuh maupun pertumbuhan panjang ikan nila.

\section{SARAN}

Disarankan pembrian ampas tahu 50\% dan pelet $50 \%$ diterapkan pada skala lebih besar misalnya sawah tambah/tambak

\section{DAFTAR PUSTAKA}

Chakraborty, S. B and S. Benerjee. 2009. Culture of Monoseks Nila Tilapia under Difeerent Traditional and Non Traditional Methods in India. Jurnal. University of Calcuta India.

Gustiano, R dan O. Z. Arifin. 2010. Budidaya Ikan Nila Best. IPB Press Bogor.

Hanafiah, K. A. 2014. Rancangan Percobaan Teori dan Aplikasi. Raja Grafindo Perkasa, Depok.

Handayani. 2006. Pemanfaatan Tepung Azola Sebagai Penyusun Pakan Ikan.

Terhadap Pertumbuhan dan Daya Cerna Ikan Nila Gilt (Oreopromis sp.). Jurnal Penelitian. Gamma Vol. 1 No, 2.
Hariyati, A. M.. 1989. Makanan Ikan Fakultas Perikanan Universitas Brawijaya Malang.

Irianto A. dan B. Austin. 2002. Use of Prebiotics to Control Furunculosis in Rainbow Trout Oncorynchus Mykiss (Walbaun) Fish Disease. 25. 333-342

Irianto, A. 2003. Probiotik Akuakuntur, Gajahmada University Press Yogyakarta.

Kordi, M. G. H. dan A. B. Tancung. 2007. Pengelolaan Kualitas Air. PT. Rineka Cipta. Jakarta.

Kordi, M. G. H, 2010. Budidaya ikan nila di kolam terpal. Lily Publiser, Yogjakarta

Mulyadi, B. S. Subaidah, S. Harjono dan Fachrurozi. 2002. Pemberian Probiotik Pada Pemeliharaan Udang Vanami (Litopenaeus Vannamei) Laporan Hasil Perekayasaan BBAP Situbondo.

Soedibyo, P. H. T. Dan A. S. Siregar. 2007. Evaluasi Penggunaan Pupuk Biostimulan Sebagai Upaya Pengkayaan Pakan Alami dan Percepatan Tumbuh Ikan Gurami (Oshphronemus Goeramy) in Hatchery Pond J. Ichthyos, 7 (1).

Wibowo. A. B. 2014. Pengaruh Penambahan Ampas Tahu yang Difermentasi Ragi Tempe dalam Pakan Komersial Terhadap Pertumbuhan Ikan Nila (Oreochromis niloticus). Fakultas MIPA Jurusan Biologi. Universitas Negeri Surakarta.

Zonneveld, N. UA Husmann dan JH Boon. 1991. Prinsip-Prinsip Budidaya Ikan. Gramedia Pustaka Utama. Jakarta 